\title{
Protection of winter spelt against fungal diseases under organic production of phyto-products in the Ukrainian polissia
}

\author{
M. M. Kliuchevych1, Yu. A. Nykytiuk ${ }^{1}$, S. H. Stoliar ${ }^{1}$, S. V. Retman², S. M. Vygera ${ }^{1}$ \\ ${ }^{1}$ Zhytomyr National Agroecological University, Ukraine \\ ${ }^{2}$ Institute for Plant Protection of NAAS of Ukraine
}

E-mail: svetlana-stolyar@ukr.net

Received: 17.02.2020 Accepted 11.03.2020

\begin{abstract}
At present, one of the main tasks is to obtain high-quality and environmentally friendly phyto-products. The interest of consumers in healthy nutrition is increasing every year. Growing plant products using organic technology is becoming widespread. Among a wide range of economic management, organic agricultural production is the only environmentally friendly method on Earth that does not inflict damage on the environment. Organic production systems are based on specific and precise requirements (standards) for the production process aimed at maintaining the optimal state of the ecosystem at the social, environmental and economic levels. The level of plant damage is controlled naturally, as well as with the help of preventive, biological and other modern scientific methods. Organic agricultural production excludes the use of artificial fertilizers and pesticides, as well as genetically modified organisms and products (substances) derived from them. The developed system for the protection of winter spelt against fungal diseases under organic production is based on biological features of mycoses, introduction of varieties with the least degree of affection by pathogens of fungal etiology, application of optimal systems of soil tilling and fertilizing, sowing time and seed application rates, as well as rational use of effective mixtures of biological preparations and plant growth regulators for seed and crop treatment. Organic protection system involves the following: complex treatment of seeds with biological preparation Agat 25-K, PA (0.04 kg/t) and plant growth regulator Biosyl $(0.01 \mathrm{l} / \mathrm{t})$ before sowing; spraying of crops at the $31 \mathrm{st}$ stage with a mixture of Agat $25-\mathrm{K}, \mathrm{PA}(0.03 \mathrm{~kg} / \mathrm{ha})+$ Biosyl $(0.01 \mathrm{l} / \mathrm{ha})$; the same treatment of crops at the 39th stage; spraying of crops with biological preparation Phytodoctor $(2.0 \mathrm{l} / \mathrm{ha})$ at the 60 th stage. Under organic production, the winter spelt yield preserved due to a set of protective measures amounts to $0.58-0.67 \mathrm{t} /$ ha or $29.6-33.7 \%$. At the same time, the protein content increases by $0.83 \%$ and gluten content by $6.9 \%$.
\end{abstract}

Key words: Winter spelt; Fungal diseases; Organic production; Protection system

\section{Introduction}

The grain husbandry of Ukraine is a strategic and the most efficient branch of the national economy. Grain and products made from it have always been liquid, since they form the basis of the food base and security of the state (Andruszczak, 2017; Havryliuk \& Krut, 2013). Unlike countries in Western Europe, Ukraine has the potential to develop and implement organic crop growing technologies over large areas.

A prerequisite for the development of organic crop husbandry and the production of environmentally friendly products is that farmers have applied significantly lower rates of agrochemicals and pesticides or have not used them at all in the last 10-15 years due to the lack of funds. Whereas in Western Europe at this time up to $350 \mathrm{~kg} / \mathrm{ha}$ of active ingredient of mineral fertilizers was applied (Horodetska \& Horodetskyi, 2017; Palamarchuk et al., 2012).

Winter spelt is the best suited crop for biologization of agricultural production. With the high general farming standards and a selfsupporting humus balance, the transition to organic farming will not lead to a decrease in crop yields (Kliuchevych, 2016). Spelt grain is valued for nutritional benefits; the flour has unique taste and high content of vitamins, protein, saturated fatty acids and fiber; soluble carbohydrates - mucopolysaccharides, contribute to the strengthening of the immune system; gluten protein includes 18 species of indispensable amino acids for the human body, a number of micro- and macronutrients (Ninieva, 2012; Gawlik-Dziki et al., 2012; Jorgensen \& Olsen, 1997). However, high and stable yields of winter spelt grain in the territory of the Ukrainian Polissia is limited by a complex of diseases, among which mycoses are the most common and harmful.

Taking into consideration that crop grain is a raw material for the production of dietetic food, special attention should be paid to environmentally safe protection against fungal diseases.

It is beyond argument that biologization and greening of intensification technologies in crop husbandry will be crucial for the increase in food production now and in the future (Wojtkowiak \& Stępień, 2015).

Many domestic and foreign scientists have been engaged in studying the problems of crop protection, among them I. M. Demchak, S. V. Dovgan, S. V. Retman, S. M. Babych, G. P. Kozak, T. I. Guk., L. Korsten, W. Elmer, J. R. Lamichhane and many others.

Some theoretical aspects of solving the problems of environmentally friendly production, in particular agricultural one, are covered in the works of T. P. Galushkina, O. I. Gutorova, L. Ye. Kupinets, Ye. V. Mishenin, V. I. Pavlov, P. M. Skrypchuk, A. I. Ukrainets, 
M. A. Khvesyk, Ye. V. Khlobystov, O. V. Khodakivska, G. V. Cherevko, O. V. Shubravska and other researchers. According to the scientists, replacement of intensive production technologies with the environmentally friendly ones will help to solve environmental and economic problems in agriculture and improve the quality of life of people (Zinovchuk \& Rashchenko, 2014).

Agricultural sector in Ukraine has undergone significant changes in recent years, especially from the standpoint of production of high-quality and safe phyto-products.

Modern organic production is characterized by a number of advantages. It is important to highlight compliance with the requirements of balanced development, meeting the needs of people in environmentally safe food products, enhancing the quality of the environment, ensuring the optimal use of non-renewable resources. However, there are still ongoing discussions among scientists and experts regarding the economic feasibility and organizational capacity of introducing organic production. The arguments in favour of traditional technologies include the following: the complexity of meeting all the technological requirements for organic farming; inability to obtain sufficient quantities of agricultural raw materials to ensure food security; lack of demand for organic products in Ukraine due to low affordability, etc.

The scientific literature does not present complex systems for protection of winter spelt against diseases in the context of organic production. At the same time, only some elements of the method of protection against phytopathogens and their influence on the productivity of crops are highlighted. Therefore, at present, it is relevant and promising to develop and implement complex organic systems for protection of spelt against mycoses in order to obtain high, stable and competitive grain yields on the low-fertility soil in the Polissia. In view of this, the purpose of our study was to develop environmentally friendly plant protection and plant products in the context of organic production, which primarily takes into account the natural regulatory mechanisms and biological method of plant protection.

This way to control the biodiversity of phytocenoses has prospects in terms of the development and implementation of scientifically and environmentally sound structure of natural, anthropo-natural and crop phytocenoses on the basis of the tripartite principle, i.e., when each of them should account for approximately 33\% (Bavec \& Bavec, 2007).

\section{Materials and Methods}

The research was conducted during 2015-2019 in the context of the experimental field of the Zhytomyr National Agroecological University (Cherniakhiv raion, Zhytomyr region). The development of organic systems for winter spelt protection was carried out on varieties with different levels of disease development, namely Oberculmer Rotcorn (high disease development) and Europe (low disease development). It was a field experiment; the size of record units was $50 \mathrm{~m}^{2}$; repetition - four times. Under organic growing technology, the investigated elements of agricultural technology, which can positively influence the regulation of mycoses in agrocenoses, were used (preceding crop, fertilizer, tillage, sowing time and seed rate). The seeds were treated with a tank mixture of the biological preparation together with a plant growth regulator on the day of seeding. Spraying of spelt was carried out at the 31st, 39th and 60th stage of plant development. Account of spelt plants diseases was conducted according to the method of V. P. Omeliuta (Omeliuta et al., 1986).

\section{Results}

In order to increase the level of effectiveness of protective measures and to avoid possible negative consequences from the application of pesticides, it is necessary to introduce an organic system of protection and apply all available methods: to stabilize the structure of acreage, to adhere to crop rotation, to grow varieties resistant to pathogens; to sow only high-quality seed treated with protection stimulating compositions; to timely and properly conduct all operations related to the technology of crop cultivation and plant protection (Figure 1) (Gawlik-Dziki et al., 2012). In order to build an effective protection system, it is above all necessary to consider the resistance of varieties to individual organisms of the pathogenic complex.

In the course of our investigation, we distinguished spelt varieties which are characterized by the smallest affection with the agents of mycosis and at the same time have high productivity. Agrotechnical measures considerably affect the formation of the yield, the level of its quality and the size of potential and actual losses caused by harmful factors. The protective function of organizational and economic measures and techniques is implemented primarily in the limitation of the disease development, increase in the stability, robustness and competitive ability of plants (Areshnikov, 1992). Tillage has traditionally been regarded as an important measure to limit the number and dispersal of harmful organisms, since one of the important sources of infection of necrotrophic pathogens is the affected plant residues.

Their embedding in the soil reduces the infectious load by 2-3 times; and with the causative agents of Septoria blight, summer patch, Ascochyta blight it completely prevents the formation of fruiting bodies (Andruszczak, 2018). According to the results of our investigation, in order to obtain high yields of winter spelt grain in the Polissia area, ploughing of the crop should be carried out to a depth of 18-20 cm. Under organic production, a fertilizer system, which involves the application of straw and sowing of the green manure crop (raphanus sativus), should be used (Vyhera et al., 2013).

According to our investigation, the use of seed disinfectants and their mixtures together with plant growth regulators ensures protection for seedlings against fungal diseases. However, only one seed treatment is not effective enough to protect the winter spelt against mycoses in the spring; instead it is advisable to spray the crops with biological preparation at the 31st and 60th stages. The use of the composition of the biological preparation Agat $25-\mathrm{K}, \mathrm{PA}(0.03 \mathrm{~kg} / \mathrm{ha})$ together with the plant growth regulator Biosyl $(0.01 \mathrm{l} / \mathrm{ha})$ increases efficiency, ensures the potential of the crop and reduces pesticidal load on agrocenosis.

It was found out that during 2015-2019 the crops of winter spelt were affected with causative agents of powdery mildew, Septoria blight, and leaf rust (Table 1 ). 


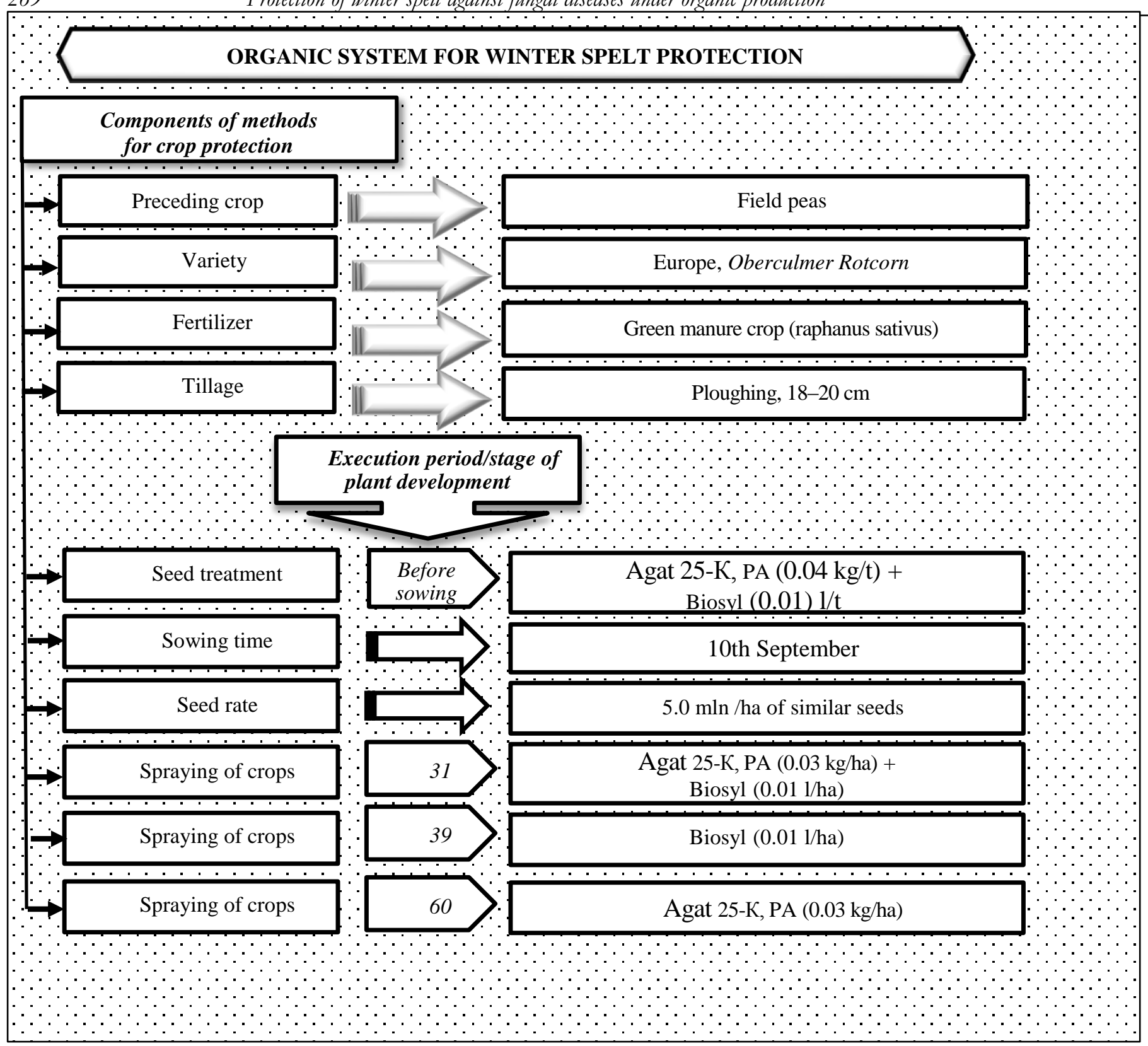

Figure 1. Components of the organic system for winter spelt protection against mycoses in the Polissia area (Experimental field of ZhNAEU, 2015-2019).

Table 1. Development of mycoses on winter spelt depending on the protection system in the Ukrainian Polissia (Experimental field of ZhNAEU, 2015-2019).

\section{Disease development, (\%)}

\begin{tabular}{|c|c|c|c|c|c|c|c|}
\hline $\begin{array}{l}\text { Protection } \\
\text { system }\end{array}$ & $\begin{array}{l}\text { powdery } \\
\text { mildew }\end{array}$ & leaf rust & $\begin{array}{c}\text { Septoria } \\
\text { blight }\end{array}$ & root rot & $\begin{array}{l}\text { powdery } \\
\text { mildew }\end{array}$ & leaf rust & $\begin{array}{c}\text { Septoria } \\
\text { blight }\end{array}$ \\
\hline & 21st stage & & & & 39th stage & 71st stage & \\
\hline \multirow{3}{*}{$\begin{array}{l}\text { Control } \\
\text { (without } \\
\text { protection) }\end{array}$} & Variety Obercul & mer Rotcorn & & & & & \\
\hline & $\begin{array}{l}2.1 \\
\text { Variety Europe }\end{array}$ & 0.7 & 1.9 & 0.9 & 8.5 & 13.0 & 15.3 \\
\hline & 0.3 & 0.2 & 0.6 & 0.2 & 2.4 & 4.4 & 3.0 \\
\hline \multirow[t]{3}{*}{ Organic } & Variety Obercu & mer Rotcorn & & & & & \\
\hline & $\begin{array}{l}1.4 \\
\text { Variety Europe }\end{array}$ & 0.4 & 1.2 & 0.5 & 3.8 & 6.5 & 7.3 \\
\hline & 0.1 & 0 & 0.3 & 0.1 & 1.1 & 2.4 & 1.6 \\
\hline HIP05 & 1.0 & 0.4 & 0.8 & 0.6 & 1.4 & 1.8 & 2.3 \\
\hline
\end{tabular}

Under the organic protection system, the development of powdery mildew on the variety Oberculmer Rotcorn at the 39th stage of development decreased by $4.7 \%$ and by $1.3 \%$ on the variety Europe compared to the control plants. At the $71 \mathrm{st}$ stage, the development of leaf rust decreased by $6.5 \%$ and $2.0 \%$, of Septoria blight by $8.0 \%$ and $1.4 \%$, respectively. 
The use of organic protection system showed high technical effectiveness against leaf diseases of winter spelt on both investigated varieties (Table 2).

Table 2. Technical effectiveness of using protection system of winter spelt in the Ukrainian Polissia (experimental field of ZhNAEU, 2015-2019).

\begin{tabular}{|c|c|c|c|c|c|c|c|}
\hline \multirow[t]{2}{*}{ Variety } & \multicolumn{7}{|c|}{ Disease development, (\%) } \\
\hline & $\begin{array}{l}\text { powdery } \\
\text { mildew }\end{array}$ & leaf rust & $\begin{array}{c}\text { Septoria } \\
\text { blight }\end{array}$ & root rot & $\begin{array}{c}\text { powdery } \\
\text { mildew }\end{array}$ & leaf rust & $\begin{array}{c}\text { Septoria } \\
\text { blight }\end{array}$ \\
\hline & 21st stage & & & & 39th stage & 71th stage & \\
\hline $\begin{array}{l}\text { Oberculmer } \\
\text { Rotcorn }\end{array}$ & 33.3 & 42.9 & 36.8 & 44.4 & 55.3 & 50.0 & 52.3 \\
\hline Europe & 66.7 & 100 & 50.0 & 50.0 & 54.2 & 45.5 & 46.7 \\
\hline
\end{tabular}

Introduction of the organic protection system of spelt against a complex of diseases contributed to the increased yield of varieties with different degrees of affection. The preserved yield amounted to $0.67 \mathrm{t} / \mathrm{ha}$ of grain for the variety Oberculmer Rotcorn and 0.58 t/ha for the variety Europe, which is $29.6 \%$ and $33.7 \%$, respectively, compared to control (Table 3 ).

Table 3. Economic efficiency of protection systems of winter spelt against mycoses in the Ukrainian Polissia (experimental field of ZhNAEU, 2015-2019).

\begin{tabular}{|c|c|c|c|}
\hline Protection system & Yield, & t/ha & Efficiency, (\%) \\
\hline \multirow{4}{*}{$\begin{array}{l}\text { Control(without } \\
\text { protection) }\end{array}$} & $\begin{array}{c}\text { Average } \\
\text { Variety Oberculmer Rotcorn }\end{array}$ &,+- compared to control & \\
\hline & 2.07 & 0 & 0 \\
\hline & Variety Europe & & \\
\hline & 2.24 & 0 & 0 \\
\hline \multirow{4}{*}{ Organic } & Variety Oberculmer Rotcorn & & \\
\hline & 2.74 & +0.67 & 29.6 \\
\hline & Variety Europe & & \\
\hline & 2.82 & +0.58 & 33.7 \\
\hline HIP05 & 0.35 & - & - \\
\hline
\end{tabular}

The use of organic protection systems of winter spelt not only provided higher yields, but also contributed to the formation of high quality grain (Table 4).

Table 4. Grain quality of winter spelt of the Europe variety depending on the protection system in the Ukrainian Polissia (experimental field of ZhNAEU, 2017-2019).

\begin{tabular}{|c|c|c|c|c|c|c|c|c|c|}
\hline \multirow{3}{*}{$\begin{array}{c}\text { Protection } \\
\text { system }\end{array}$} & \multicolumn{9}{|c|}{ Content in grain, (\%) } \\
\hline & & & $\begin{array}{r}\text { Fibre } \\
\mathbf{q}\end{array}$ & & & & & & \\
\hline & protein & $\%$ & $\begin{array}{l}\text { VDK, } \\
\text { pcs. }\end{array}$ & group & ash & fat & starch & $\mathbf{P}_{2} \mathbf{O}_{5}$ & $\mathbf{K}_{2} \mathrm{O}$ \\
\hline $\begin{array}{l}\text { Control } \\
\text { (without } \\
\text { protection) }\end{array}$ & 10.57 & 19.1 & 85 & II & 1.23 & 1.73 & 56.0 & 0.85 & 0.56 \\
\hline Organic & 11.4 & 26.0 & 95 & II & 1.25 & 1.78 & 53.9 & 0.88 & 0.56 \\
\hline
\end{tabular}

The influence of the protection systems of winter spelt against mycoses on the qualitative indicators of grain was analysed for the variety Europe for the yields from 2017-2019. It was found out that the qualitative indicators exceeded the control in terms of protein content by 0.83 , of gluten by $6.9 \%$.

\section{Testing the results of the study}

The developed measures of protection have passed a production check at the agricultural enterprises: LLC Staryi Porytsk in Volyn region (40 hectares); Farm Enterprise Makyshynskyi Sad in Chernihiv region (110 ha). The preserved harvest amounted to $0.75-$ $0.79 \mathrm{t} / \mathrm{ha}$. The results of the study can be used by producers to plan a protection system of winter spelt against mycosis in the Ukrainian Polissia.

\section{Discussion}

It should be emphasized that the organic production is an integral system and consists of a number of elements, in particular: organizational and technological - legal - certification based on international standards - cultivation of raw materials - harvesting, storage and transportation of raw materials - processing of raw materials and obtaining high-quality and safe products transportation and storage of products - sales of products - consumption of products, etc. Each of these elements has its own specific features in terms of plant protection, especially when growing raw materials. 
Organic production is aimed at obtaining high-quality safe plant products while minimizing the negative impact on the environment, so conditions of organic production imply special requirements for protection of agricultural crops (Makarenko et al., 2014).

The main requirements for preparations used in organic production are national and international, so the main criteria for pesticide assessment should be the following (Makarenko et al., 2014): compulsory natural origin of the preparations (animal, microbial or mineral); method of obtaining preparation (technology of preparation and other substances used in the production process); absence of negative effect on the environment and ecotoxicological evaluation of the active ingredient and auxiliary components of the preparation; obligatory inclusion of the preparation or active ingredients in the list of certified.

Creation and introduction into production of agricultural crop samples with high resistance to pests has been and remains one of the progressive directions of agronomy, which is impossible without studying and amplification of the species composition of pathogens of fungal diseases, features of their development in various agro-climatic zones of Ukraine. Selection for resistance is one of the ways to reduce the cost of chemical crop protection and moderate the environmental pressure on agrocenosis in general. This is the first step in obtaining organic agricultural products (Babenko et al., 2014).

Since the use of mineral fertilizers is unacceptable in organic agricultural production technology, the cheapest substitute is the green manure. The green mass of green manure crops is plowed when it is juicy and has high water content, so it decomposes and releases nitrogen more quickly than farmyard manure. The best green manure crops are legumes, which can be an interplanted crop after the harvest of annual grasses of different grain crops (winter barley, winter rape, winter cress) and winter cereals harvested in July.

For this purpose, peas, field peas, vetch, beans, and lupine are used; they provide a yield of green mass of more than 10 tons/ha. It is known that spelt is affected by the agents of leaf rust and powdery mildew (Janković et al., 2013; Ruegger et al.,1990); although some scientists (Schobera et al., 2006; Martin et al., 1991; Polley \& Thomas,1991) claim that this crop has high disease resistance. Given the limited information on spelt diseases and measures for protection against them, it should be noted that the issue of monitoring the development of winter spelt diseases in the Ukrainian Polissia, the development and implementation of an effective organic protection system is necessary and relevant.

\section{Conclusion}

The developed protection systems of winter spelt make it possible for agricultural producers of various forms of ownership to effectively regulate the development of mycoses on the crop, to obtain sustainable grain yield with good marketable and sowing qualities by means of organic growing technology. Under organic production, a protection system was developed in order to grow spelt. The system involves the following: a complex treatment of seeds with biological preparation Agat 25-K, PA, 0.04 kg/t and plant growth regulator Biosyl, $0.01 \mathrm{l} / \mathrm{t}$ before sowing; spraying of crops at the 31st stage with a mixture of Agat $25-\mathrm{K}, \mathrm{PA}, 0.03 \mathrm{~kg}+$ Biosyl, $0.01 \mathrm{l} / \mathrm{ha}$, and the same spraying at the $39^{\text {th }}$ stage; spraying of crops with biological preparation Phytodoctor, $2.0 \mathrm{l} /$ ha at the 60 th stage. Under organic system, due to a set of protecting measures the amount of preserved yield of winter spelt was $0.58-0.67$ $\mathrm{t} / \mathrm{ha}$. In addition, the protein and gluten content increases. Further study will focus on establishing the etiology of the pathogenic complex of winter spelt and also on developing and improving the effective measures of pest control in agrocenoses in the context of organic production.

\section{References}

Andruszczak, S. (2017). Reaction of winter spelt cultivars to reduced tillage system and chemical plant protection. ZemdirbysteAgriculture, 104(1), 15-22. doi: 10.13080/z-a.2017.104.003.

Havryliuk, L. L., Krut. M. V. (2013). Plant protection innovations - production. Protection and quarantine of plants, 59, 12-18. (in Ukrainian).

Palamarchuk, V. D., Polishchuk, I. S., Ermakova, L. M., Kalenska, S. N. (2012). The system of modern intensive technologies in crop. Vinnytsia: FOP Rogalskyy I. O.

Horodetska, O. O, Horodetskyi, O. S. (2017) Peredumovy zaprovadzhennia orhanichnoi tekhnolohii vyroshchuvannia pshenytsi ozymoi. Ahrobiolohiia, 1, 42-48. (in Ukrainian).

Kliuchevych, M. M. (2016). Kontrol mikoziv spelty ozymoi v umovakh Polissia Ukrainy. Karantyn i zakhyst Roslyn, 1, 1-3. (in Ukrainian).

Jorgensen, J. R, Olsen, C. C. (1997). Yield and quality assessment of spelt (Triticum spelta L.) compared with winter wheat ( Triticum aestivum L.) in Denmark. In: Spelt and Quina. Working Group Meeting. Wageningen.

Ninieva, A. K. (2012). Henetychne riznomanittia spelty ozymoi za hospodarskymy oznakamy v umovakh skhidnoi chastyny Lisostepu Ukrainy. Selektsiia i nasinnytstvo, 101, 156-167. (in Ukrainian).

Gawlik-Dziki, U., Świeca, M., Dziki, D. (2012). Comparison of phenolic acids profile and antioxidant potential of six varietes of spelt (Triticum spelta L.). Journal of Agriculture and Food Chemistry, 60 (18), 4603-4612. doi.org/10.1021/jf3011239

Wojtkowiak, K., Stępień, A. (2015). Nutritive value of spelt (Triticum aestivum spp. spelta L.) as influenced by the foliar application of copper, zinc and manganese. ZemdirbysteAgriculture, 102(4), 389-396. doi.org/10.13080/z-a.2015.102.049.

Zinovchuk, N. V, Rashchenko, A. V. (2014). Osoblyvosti vprovadzhennia vyrobnytstva orhanichnoi produktsii v Ukraini. Zbalansovane pryrodokorystuvannia, 1, 13-20. (in Ukrainian).

Bavec, F. and Bavec, M. (2007). Organic production and use of alternative crops. CRC Press. Boca Raton, Floride.

Omeliuta, V. P, Hryhorovych, I. V, Chaban, V. S. (1986). Oblik shkidnykiv i khvorob silskohospodarskykh kultur. Kyiv: Urozhai. (in Ukrainian).

Gawlik-Dziki, U., Świeca, M., Dziki, D. (2012). Comparison of phenolic acids profile and antioxidant potential of six varietes of spelt (Triticum spelta L.). Journal of Agriculture and Food Chemistry, 60(18), 4603-4612. doi.org/10.1021/jf3011239.

Areshnikov, B. A. (1992). Zakhyst zernovykh kultur vid shkidnykiv, khvorob i burianiv pry intensyvnykh tekhnolohiiakh. Kyiv: Urozhai. (in Ukrainian).

Andruszczak, S. (2018): Spelt wheat grain yield and nutritional value response to sowing rate and nitrogen fertilization. The Journal of Animal \& Plant Sciences, 28(5), 1476-1484.

Vyhera, S. M, Ivanenko, O. A, Kliuchevych, M. M. (2013). Kontseptsiia zakhystu roslyn pry orhanichnomu vyrobnytstvi fito produktsii. Honcharivski chytannia. Zb. tez mizhnar. nauk.-prakt. konf., prysviach. 84-richchiu z dnia narodzh. doktora s.-h. nauk, prof. M. D. Honcharova. Sumy. Sumy: Sumskyi NAU. (in Ukrainian). 
Makarenko, N. A, Salnykova, A. V, Bondar, V. I. (2014). Prydatnist pestytsydiv dlia zakhystu silskohospodarskykh roslyn $v$ orhanichnomu vyrobnytstvi. Karantyn i zakhyst roslyn, 12, 3-4. (in Ukrainian).

Babenko, L. M., Hospodarenko, H. M., Rozhkov, R. V., Pariy, Y. F., Pariy, M. F., Babenko, A. V., Kosakivska, I. V. (2018): Triticum spelta: Origin, biological characteristics and perspectives for use in breeding and agriculture. Regulatory Mechanisms in Biosystems, $9(2), 250-257$.

Ruegger, A., Winzeler, H., Nosberger, J. (1990). Dry natter production and distribution of Cassimilates of spelt (Tritikum spelta L.) und wheat (Triticum aestivum L.) as influenced by different tem peratures before and during grain illing. Journal of Agronomy and Crop Science, 165(2-3), 110-20.

Janković, S., Ikanović, J., Popović, V., Rakić, S., Kuzevski, J. (2013). Agro-ecological conditions and morphoproductive properties of spelt wheat. Biotechnology in Animal Husbandry, 29(3), 547-554.

Schobera, T. J., Beana, S. R., Kuhn, M. G (2006) Luten proteins from spelt (Triticum 165 aestivum ssp. spelta) cultivars: A rheological and size-exclusion highperform ance liquid chrom atography study. Journal of Cereal Science. 44, 161-173.

Martin, R. A., Macleod, J. A., Caldwell, C. (1991). Influences of Production Inputs on Incidence of Infection by Fusarium Species on Cereal Seed. Plant Disease, 75(8), 784-788.

Polley, R. W, Thomas, M. R. (1991). Surveys of diseases of winter wheat in England and Wales, 1976-1988. Ann. Appl. Biol., 119, $1-20$.

\section{Citation:}

Kliuchevych, M.M., Nykytiuk, Yu.A., Stoliar, SH., Retman, S.V., Vygera, S.M. (2020). Protection of winter spelt against fungal diseases under organic production of phyto-products in the Ukrainian polissia. Ukrainian Journal of Ecology, 10(1), 267-272. 